the mice. That move shifted the lawsuit to the federal government - a more costly and formidable defendant to take on in court.

The AIA dropped its case in 2011, and lawsuits that it had filed against other biomedical companies were eventually tossed out as well.

But these cases exacted a toll: all together, they amounted to some 18.7 cumulative court years in 6 jurisdictions, involved at least 98 lawyers and produced 1,143 court filings ${ }^{2}$. The lawsuits also raised concerns that the AIA would sue researchers who had used the mice in question. This was a fear that, the Jackson Lab argued, hindered researchers from sending mouse strains to facilities such as theirs for maintenance and distribution.

\section{COURTING COMPLICATIONS}

Nevertheless, the USF decided to pick up where the AIA left off, by suing both the NIH and the Jackson Lab in 2015 over its double-mutant mice. If the university is successful, it could entice others to follow suit, says Tania Bubela, a legal scholar at the University of Alberta in Edmonton, Canada.

But such lawsuits could risk damaging an academic institution's reputation, Bubela adds. "Whether other universities are crazy enough to follow the lead of the University of South Florida is another question," she says. "I can't imagine more research-intensive universities engaging in this kind of behaviour."

Two researchers formerly at the USF who are listed as inventors on the university's double-mutant-mouse patent - neuroscientists Karen Duff, now at Columbia University in New York City, and John Hardy, now at University College London - declined to comment specifically on the current lawsuit. A lawyer for the USF also did not comment on the case. But Hardy says: "I do think these things are better sorted out without recourse to lawyers and the courts."

The case is unlikely to set Alzheimer's research back if access to the mice is restricted as a result of the lawsuit, says neuroscientist Sangram Sisodia of the University of Chicago in Illinois. Several alternative models have been developed since the Nature publication in 1998 that first described the USF double-mutant mouse ${ }^{1}$. In 2001, for example, a team led by neuroscientist David Borchelt at the University of Florida in Gainsville described a way of introducing the two mutated genes in one step ${ }^{3}$. "It saved a lot of time and money," says Sisodia.

Sisodia's team developed a double-mutant mouse ${ }^{4}$ similar to the USF's version before Hardy and Duff described their mutants. Did Sisodia want to patent his mice? "No," he says: "Not interested." -

1. Holcomb, L. et al. Nature Med. 4, 97-100 (1998).

2. Bubela, T., Vishnubhakat, S. \& Cook-Deegan, R. J. Law Biosci. 2, 213-262 (2015).

3. Janowsky, J. et al. Biomol. Eng. 17, 157-165 (2001).

4. Borchelt, D. et al. Neuron 5, 1005-1013 (1996).

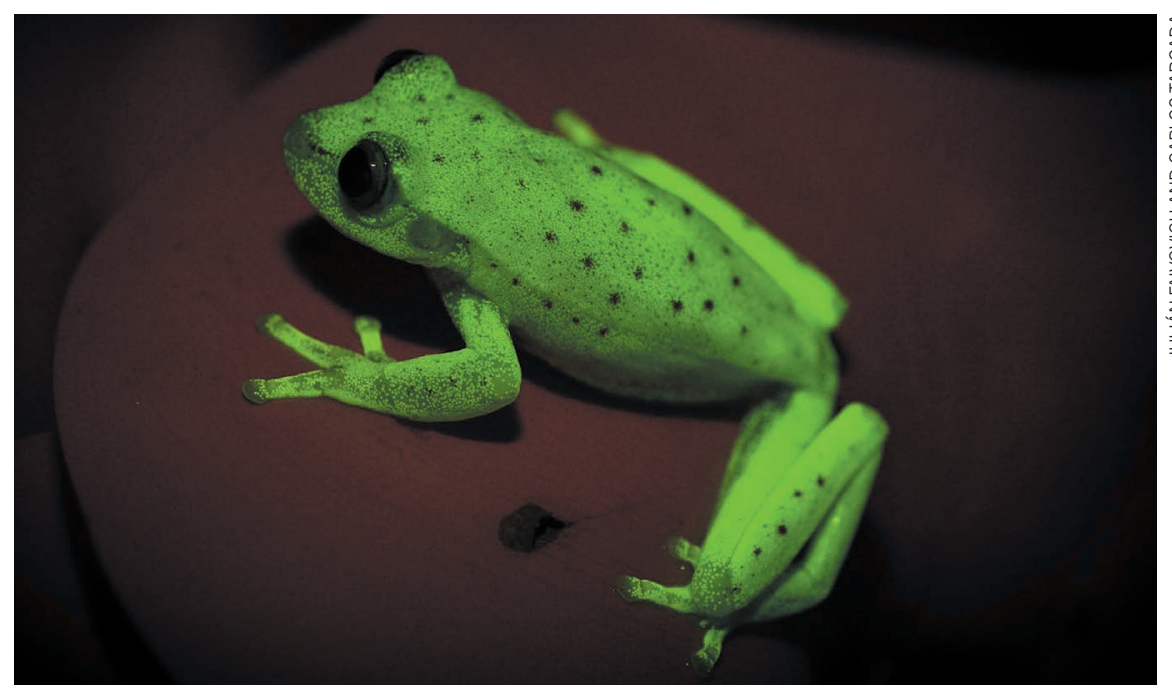

Fluorescent molecules in this male polka-dot tree frog turn it into a night light.

\title{
BIOLOGY
}

\section{First fluorescent frog found}

\section{Rare discovery in a land animal reveals a new way to glow.}

\section{BY ANNA NOWOGRODZKI}

$\mathrm{U}$ nder normal light, the South American polka-dot tree frog (Hypsiboas punctatus) sports a muted palette of greens, yellows and reds. But switch on ultraviolet illumination, and this little amphibian gives off a bright green glow.

The ability to absorb light at short wavelengths and re-emit it at longer wavelengths is called fluorescence. The phenomenon is rare in land animals and, until now, was unheard of in amphibians. Researchers also report that the frog uses fluorescent molecules unlike those found in other animals; they published the find on 13 March (C. Taboada et al. Proc. Natl Acad. Sci. USA http://doi.org/b364; 2017).

Fluorescence is distinct from bioluminescence, in which organisms give off light generated by chemical reactions. Many ocean creatures fluoresce, including corals, fish and sharks. On land, fluorescence was previously known only in parrots and some scorpions. It is unclear why animals have this ability, although explanations include communication and camouflage.

The researchers first thought that they might find red fluorescence in these frogs, because the creatures contain a pigment called biliverdin. By itself, biliverdin turns the amphibian's tissues and bones green. However, in some insects, proteins that bind to biliverdin emit a faint red fluorescence, says study co-author Carlos Taboada, a herpetologist at the University of Buenos Aires. When researchers used a UV light on polka-dot tree frogs collected near Santa Fe, Argentina, the animals gave off an intense green glow instead.

Three molecules in the animals' lymph tissue, skin and glandular secretions were responsible for the green fluorescence. The molecules contain a ring structure and a chain of hydrocarbons, and are unique among known animal fluorescent molecules. The closest similar molecules are found in plants, says study co-author Norberto Peporine Lopes, a chemist at the University of São Paulo in Brazil.

The fluorescent molecules are bright, providing about $18 \%$ as much visible light as a full Moon. The polka-dot tree frog's visual system remains a mystery, so Taboada plans to study it to determine whether the amphibians can see their own fluorescence.

"I think it's exciting," says marine biologist David Gruber of Baruch College, part of the City University of New York, who with his colleague discovered fluorescence in hawksbill sea turtles (Eretmochelys imbricata) in 2015 (D. F. Gruber and J. S. Sparks Am. Mus. Novit. 3845, 1-8; 2015). "It opens up many more questions than are answered," he says — including the ecological and behavioural function of fluorescence. 